\title{
Consumer behavior: conditioners on the purchase decision of fluid milk
}

\author{
Raquel Breitenbach $^{1^{*}}$ (iD) Janaína Balk Brandão ${ }^{2}$ iD
}

\begin{abstract}
${ }^{1}$ Instituto Federal de Educação, Ciência e Tecnologia do Rio Grande do Sul (IFRS), RS. 99170-000, Sertão, RS, Brasil. E-mail: raquel. breitenbach@sertao.ifrs.edu.br. *Corresponding author.

${ }^{2}$ Programa de Pós-Graduação em Extensão Rural, Departamento de Educação Agrícola e Extensão Rural, Universidade Federal de Santa Maria (UFSM), Av. Roraima, 1000, Bairro Camobi, Santa Maria, RS, Brasil.
\end{abstract}

ABSTRACT: Considering economic, contingent and cultural conditions that interfere with consumer demand, the objective of this research was to evaluate the degree of importance of these variables in the decision of the Brazilian consumer to buy fluid milk. A total 1,015 milk consumers were sampled through non-probabilistic tools such as researchers' contact network, snowballing, and self-generated samples, in a virtual questionnaire. Non-parametric tests and univariate statistical analyzes were applied, including the chi-square test. The consumer profile interferes with the selection criteria in the purchase of fluid milk as follows: (a) women consider "price", "product origin", "friend recommendation", "product appearance", "sales offers", and "brand" as the most important conditioners; (b) young people, aged between 18 and 25, consider "product origin" a less important attribute; (c) consumers over 45 years of age value "price” the less; (d) consumers with incomes of up to one minimum wage value "sales offers" the most. This research theoretically confirmed the hypothesis that prior information regarding milk production, especially brands, lead the decision to buy fluid milk, especially in women case. Product price and availability are complementary constraints.

Key words: brands, price, women.

Comportamento do consumidor: condicionadores na decisão de aquisição de leite fluido

RESUMO: Considerando condições econômicas, contingênciais e culturais que interferem na demanda do consumidor, o objetivo desta pesquisa foi avaliar o grau de importância dessas variáveis na decisão do consumidor brasileiro de comprar leite fluido. Um total de 1.015 consumidores de leite foi pesquisado por meio de ferramentas não probabilisticas, como rede de contatos de pesquisadores, bola de neve e amostras autogeradas, em um questionário virtual. Testes não paramétricos e análises estatísticas univariadas foram aplicados, incluindo o teste qui-quadrado. O perfil do consumidor interfere com os critérios de seleção na compra de leite fluido da seguinte forma: (a) as mulheres consideram "preço", "origem do produto", "recomendação de amigos", "aparência do produto", "ofertas de venda" $e$ "marca" como os condicionantes mais importantes; (b) os jovens, com idade entre 18 e 25 anos, consideram a "origem do produto" um atributo menos importante; (c) consumidores com mais de 45 anos de idade valorizam menos a variável "preço"; (d) os consumidores com renda de até um salário mínimo valorizam as "ofertas de venda". Esta pesquisa teoricamente confirma a hipótese de que informações prévias sobre a produção de leite, principalmente as marcas, levam à decisão de comprar leite fluido, especialmente no caso das mulheres. O preço e a disponibilidade do produto são restrições complementares.

Palavras-chave: marcas, preço, mulheres.

\section{INTRODUCTION}

The postmodern world requires a broader view of food supply. Consumers take on a central role among other links of production chains, demanding greater attention to the marketing sector from companies. This sector aims to create value for its clients, seeking to understand their thoughts, actions, motivations and influences in the process of buying (CHURCHILL \& PETER, 2003). The first step is to understand which individuals compose the consumer audience to understand how interpersonal and intrapersonal relations interfere in purchasing decisions and buying dynamics (SANDHUSEN, 2010).
The processes of buying and consumers' decisions are influenced by several factors that must be known by the companies. Product launches and services are improved, distribution may be better planned, and price policies are adjusted according to market reality. Moreover, the company is promoted according to customers' expectations using media reaching target market.

Even though milk demand has been on the rise, consumers seek better product quality. Especially the following aspects affect milk consumption in Brazil: a) Economic: variation in population income (ASSIS et al., 2017) with a reduction of their purchasing power given income decrease.

b) Contingencies: adulteration and contamination 
scandals that reduce demand in the formal market and boost demand in the informal market (BRANDÃO et al., 2015; BREITENBACH et al., 2018).

c) Cultural: related to lack of consumer information, especially regarding milk benefits to human health (CHAVES et al., 2016), and based on consumer taste and habits (SOUZA et al., 2013; CHAVES et al., 2016) who may migrate to other products they consider as substitutes.

d) Brazilian policies: impact of the Federal Government's demand on the expansion of institutional programs for purchase and distribution of milk and milk products; as well as the possibility of implementing initiatives to increase milk and milk product consumption, stimulating its consumption and adjusting supply and demand (MAPA, 2011).

In order to understand consumer behavior in relation to bovine milk consumption, the HOWARD Model (1989) was used. The three central components of Howard's structure, recognition, attitude toward brand and trust, form the brand perception image and result in the consumer's total knowledge of a particular brand or product (HOWARD, 1989; LOPES \& SILVA, 2011). This model covers the possibility of a purchase decision based on the complexity of the purchase and the information available to the consumer, such as purchase of new or newly launched products, complex purchasing decisions and routine purchasing decisions.

In this study, the scope of "routine acquisitions" was considered relevant, in which both attitude and confidence in the product as well as brand recognition exist before buying, given previous experience on prior purchases (LOPES \& SILVA, 2011). Therefore, based on the Howard model, it is assumed that information obtained regarding product from prior purchases and research experiences is unlikely to overlap with brand recognition, attitude and trust (HOWARD, 1989). Even so, information can affect the intention of purchase, for example, choosing a cheaper brand or one with immediate availability (LOPES \& SILVA, 2011).

Considering the context of constraints (economic, contingent, and cultural) that interfere with milk demand, the present study sought to evaluate the decisive variables in the purchase of cow milk, specifically to verify if there are differences in consumption behavior patterns based on consumer profile, analyzing the influence of age, gender and income in decision-making about the purchase of fluid milk. The objective is to establish the main criteria for product selection to obtain information on consumer motivators, as well as information to quantify and understand consumer relations of fluid milk in Brazil.

\section{METHODOLOGY}

This research is quantitative and qualitative and used the survey strategy. Sampling was nonprobabilistic for convenience and counted on the responses of 1,015 milk consumers. Non-probabilistic samples are not intended to be representative of the population. Subjective methods are used to select respondents, since their probability of choice is not known (HAIR et al., 2005).

The contact network of the research team of the Federal Institute of Education, Science and Technology of Rio Grande do Sul's project entitled "Milk Fraud and Consumer Perception" was used for sampling. It was complemented with the snowball technique (MATTAR, 2007; MALHOTRA, 2001) and self-generated sample. Self-generated samples are determined when respondents refer new people to be sampled, such as acquaintances, personal or professional networks (MALHOTRA, 2001). Snowball sampling is used when an initial probabilistic sample is impossible or impractical. Once the first contacts are made, they help the researcher by indicating new contacts with the desired characteristics from their own personal network and so on (VINUTO, 2014).

The profile of the 1,051 consumers sampled is shown in Table 1. The questionnaire was disseminated in social networks and other social and entertainment relations, made available in specialized websites in the area of the milk production chain and also distributed via e-mail. Use of Internet surveys is characteristically fast and cheap compared to telephone surveys, post office use, or personal interviews (MALHOTRA, 2001).

Criteria and analysis variables

In order to identify the importance milk consumers attribute to different aspects when buying fluid milk, the following variables were selected for each conditioner listed: (a) economic: price and sales offers; (b) contingencies: known brands and friend's recommendation; (c) cultural: region of milk origin and label/design.

The questionnaire was elaborated based on the three conditioners groups and their respective variables (Table2). It is a "standardization" instrument, through which one can assure the equivalence of different opinions and attitudes, with the ability to compare them (MARCONI \& LAKATOS, 2010). Using Likert scales, the questionnaire contained 14 
Table 1 - Profile of the milk consumers participating in the research.

\begin{tabular}{|c|c|c|}
\hline Profile indicators & Categorization of the consumer profile & Percentage of consumers \\
\hline \multirow{2}{*}{ Gender } & Male & 45.5 \\
\hline & Female & 54.4 \\
\hline \multirow{6}{*}{ Scholarity } & Elementary School Incomplete & 0.1 \\
\hline & Elementary School Complete & 0.1 \\
\hline & Incomplete High School & 1.2 \\
\hline & Complete High School & 3.5 \\
\hline & Incomplete Higher Education & 25.6 \\
\hline & Full Higher Education & 69.6 \\
\hline \multirow{4}{*}{ Age } & 18 to 25 years & 25.1 \\
\hline & 26 to 35 years & 36.3 \\
\hline & 36 to 45 years & 23.3 \\
\hline & above 45 years & 15.4 \\
\hline \multirow{7}{*}{ Family income } & Up to 1 minimum wage & 2.2 \\
\hline & 1 to 2 minimum wages & 7.3 \\
\hline & 2 to 3 minimum wages & 11.1 \\
\hline & 3 to 4 minimum wages & 9.7 \\
\hline & 4 to 5 minimum wages & 10.3 \\
\hline & 5 to 6 minimum wages & 11.4 \\
\hline & above 6 minimum wages & 48.1 \\
\hline \multirow{6}{*}{$\begin{array}{l}\text { People in the family who } \\
\text { consume milk }\end{array}$} & 1 & 12.0 \\
\hline & 2 & 28.7 \\
\hline & 3 & 22.7 \\
\hline & 4 & 21.5 \\
\hline & 5 & 10.8 \\
\hline & Above 5 & 4.3 \\
\hline
\end{tabular}

questions distributed in four sections, regarding opinion and attitudes. It was available online for completion; -therefore, not answered in the presence of the researcher- between September 18 and October 21, 2017.

From the data of the tabulated questionnaires, non-parametric tests were applied and univariate statistical analyzes were performed, including the Chisquare test, using the open source PSPP software. The level of significance applied to the chi-square test was lower than or equal $(\leq)$ to 0.005 .

\section{RESULTS AND DISCUSSION}

Conditions of fluid milk purchase were individually investigated as to their importance in consumer's choice and purchase. They are: "known brands", "region of milk origin, "price", "friend's recommendation", "label/design", and "promotional offers". Results of this empirical investigation can be seen in figure 1.
Among analyzed items, "brand" stood out the most, demonstrating its relevance to the consumer. Most milk consumers have a preferred brand and are loyal to it (CHAVES et al., 2016). A differential in the milk production chain is when the sector can create and consolidate dairy brands that pass a good market image to the consumer (BREITENBACH et al., 2018). Especially after 2013, after fraud episodes, consumers' trust on processing companies reduced $51 \%$ (BREITENBACH et al., 2018), reiterating the relevance of strengthening brands as a business strategy. This research corroborated Howard's eclectic model (1989), where brand is considered important in the purchasing decision process and a result of search and information analysis (MAHAJAN et al. 1990; LOPES \& SILVA, 2011).

However, brand loyalty is more a behavioral issue than just product preference (CHAVES et al., 2016). Therefore, it is important to win over the consumer not just via the product, but also appealing to other factors associated with purchase behavior. 
Table 2- Organization and composition of the research instrument.

\begin{tabular}{|c|c|}
\hline Criteria & Questions \\
\hline $\begin{array}{l}\text { Consumer profile } \\
\text { and characteristics }\end{array}$ & $\begin{array}{c}\text { 1. Gender. } \\
\text { 2. City / Municipality / State. } \\
\text { 3. Age. } \\
\text { 4. Training / Schooling. } \\
\text { 5. Do you work and / or study in agribusiness / agrarian sciences? } \\
\text { 6. Family Income R \$. } \\
\text { 7. Are you a consumer of fluid milk? } \\
\text { 8. How many people live with you and consume milk? }\end{array}$ \\
\hline $\begin{array}{l}\text { Consumer Habits - } \\
\text { Economic Criterion }\end{array}$ & $\begin{array}{l}\text { 9. Consider the importance of Price when buying / buying fluid milk? ( )Not important ( )Little } \\
\text { Importance ( )Importance ( ) Very important } \\
\text { 10.Consider the importance of Promotional Offers when purchasing / buying fluid milk? ( )Not } \\
\text { important ( )Little Importance ( )Importance ( ) Very important }\end{array}$ \\
\hline $\begin{array}{l}\text { Consumer Habits - } \\
\text { Contingency } \\
\text { Criterion }\end{array}$ & $\begin{array}{l}\text { 11. Consider the importance of Brand that I already know when buying / buying fluid milk? ( )Not } \\
\text { important ( )Little Importance ( )Importance ( ) Very important } \\
\text { 12.Consider the importance of recommending friends when purchasing / buying fluid milk? ( )Not } \\
\text { important ( )Little Importance ( )Importance ( ) Very important }\end{array}$ \\
\hline $\begin{array}{l}\text { Habits of } \\
\text { consumption - } \\
\text { Cultural Criteria }\end{array}$ & $\begin{array}{l}\text { 13.Consider the importance of Region of origin of milk when buying / buying fluid milk? ( )Not } \\
\text { important ( )Little Importance ( )Importance ( )Very important } \\
\text { 14.Consider the importance of appearance as a label/design when acquiring/buying fluid milk? ()Not } \\
\text { important ()Little Importance ()Importance ()Very important }\end{array}$ \\
\hline
\end{tabular}

Company (and its brands) tradition, including packaging quality and official certification, represent relevant factors in credibility formation for dairy consumption (LEITE et al., 2013).

"Price" was the next highlighted item. This factor was "very important" for $20 \%$ of consumers, and $47 \%$ consider it "important" at purchase time. DÖRR \& NASCIMENTO (2010) reported that $64 \%$ of consumers took price into consideration in the acquisition of fluid milk. Assessing "promotional offers", $47 \%$ of consumers consider the factor very important or important. Promotional offers are attractive to the consumer, seducing customers who hardly buy only the product on sale (MARANDOLA \& LEMANSKI, 2006).

When considering "friend's recommendation", results showed that this factor has a small impact on the decision - of purchase fluid milk, since only $8 \%$ of consumers considered the factor to be very important. Added to this, also only $9 \%$ of respondents considered "label/design" very important in the purchase decision. This is confirmed by the fact that the milk cartons, known in Brazil as "longer shelf life package", have a design that seeks to meet the needs of people for more nutrition and health. However, it does not concern the consumer who is entitled to the correct, clear and accurate information on the quality, quantity, composition, price, warranty, shelf life, origin and risks that the product presents for consumer health and safety. Companies failing to provide this type of information on packaging labels appear to be disrespectful to the consumer (BOTELHO et al., 2015). Moreover, the consumer has preferred packaging easier to handle and serve the milk, and packaging with illustrations associated with milk (CHAVES et al., 2016).

Correlation between consumer profile and consumption constraints

Consumer profile data, as well as the information referring to consumption conditions, was used to answer the specific research objectives individually, correlating each profile characteristic with each consumption condition. Behavioral patterns related to age, gender, income, schooling, and milkconsuming family member amount were verified. Table 3 shows statistically significant correlations according to chi-square test after crossing profile variables with consumption conditioners variables.

Three elements appear as key variables in terms of correlation and significance in the behavior of Brazilian fluid milk consumers:

a) Regarding gender: Women, unlike men, showed significant correlations to all six variables listed, including price. There are enough reasons for retailers to study the effect that gender difference has on marketing and sales processes, especially 


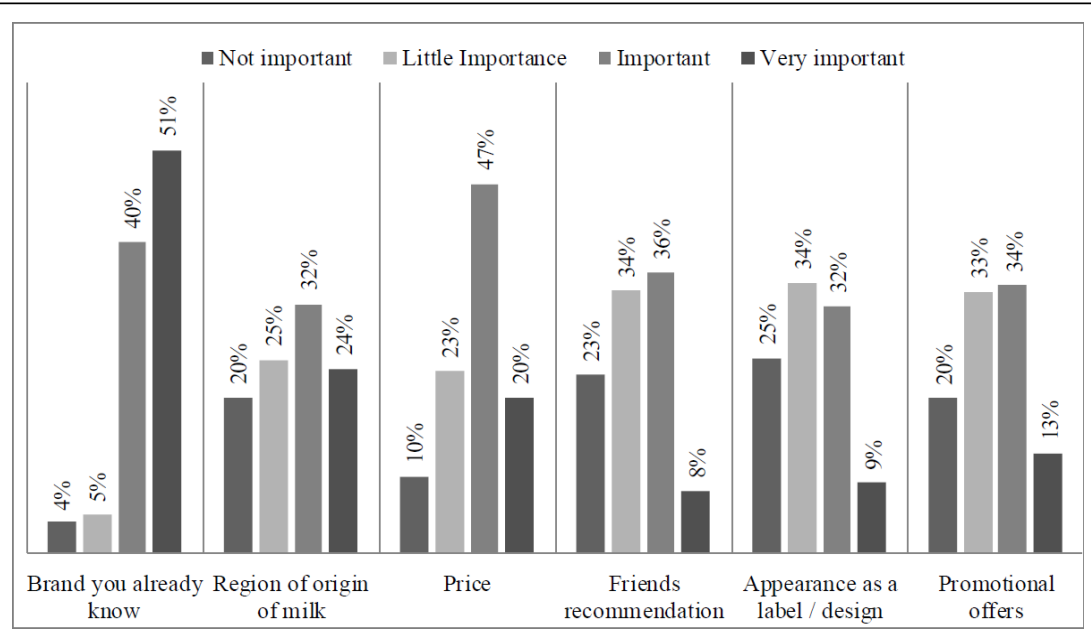

Figure 1 - Degree of importance that the consumer attributes to the different conditioning factors when choosing fluid milk.

the importance of emotional subtleties in women's decision making (BRENNAN, 2011). In every society in the world, no matter how advanced, women remain responsible for caring for food, home, and children, and this behavior has an impact on shopping (BRENNAN, 2011).

The differentiation of women's behavior still occurs in terms of demand. Women are responsible for buying or influencing the purchase of $80 \%$ of consumer goods (JOHNSON \& LEARNED, 2012). The high female buying and decision power draws attention to the companies' marketing strategies (JATO \& LICHT, 2009).

b) Regarding age: The survey pointed out that younger consumers do not care where the product originates. Other studies have concluded that they do

Table 3 - Correlations of the Brazilian fluid milk consumer profile with consumption constraints.

\begin{tabular}{|c|c|c|}
\hline Variables & Significance & Test Chi Square \\
\hline Gender versus price & Women value more than men the "price" attribute when buying milk. & $\mathrm{p}=0.000$ \\
\hline $\begin{array}{l}\text { Gender versus product } \\
\text { origin }\end{array}$ & $\begin{array}{l}\text { Women value more than men the attribute "place of origin of the product" at the } \\
\text { time of purchase of the milk. }\end{array}$ & $\mathrm{p}=0.001$ \\
\hline $\begin{array}{l}\text { Gender versus friends } \\
\text { recommendation }\end{array}$ & $\begin{array}{l}\text { Women value more than men the attribute "recommendation of friends" when } \\
\text { buying milk. }\end{array}$ & $\mathrm{p}=0.002$ \\
\hline $\begin{array}{l}\text { Gender versus product } \\
\text { appearance }\end{array}$ & $\begin{array}{c}\text { Women value more than men the "product appearance" attribute when buying } \\
\text { milk. }\end{array}$ & $\mathrm{p}=0.001$ \\
\hline $\begin{array}{l}\text { Gender versus promotional } \\
\text { offers }\end{array}$ & Women value more than men "promotional offers" at the time of buying milk. & $\mathrm{p}=0.000$ \\
\hline $\begin{array}{l}\text { Gender versus choice of } \\
\text { brands }\end{array}$ & Women choose more brands at the time of buying milk than men. & $\mathrm{p}=0.002$ \\
\hline Age versus product origin & $\begin{array}{l}\text { Consumers in the age group of } 18 \text { to } 25 \text { years do not value the attribute "origin of } \\
\text { the product" at the time of the purchase of milk. }\end{array}$ & $\mathrm{p}=0.000$ \\
\hline Age versus price & $\begin{array}{c}\text { Consumers over } 45 \text { years of age are the ones who value the "product price" } \\
\text { attribute at the time of milk purchase. }\end{array}$ & $\mathrm{p}=0.001$ \\
\hline $\begin{array}{l}\text { Income versus promotional } \\
\text { offers }\end{array}$ & $\begin{array}{l}\text { Consumers with incomes of up to one minimum wage value the attribute } \\
\text { "promotional offers" at the time of buying milk more than those who are in the } \\
\text { other income brackets. }\end{array}$ & $\mathrm{p}=0.000$ \\
\hline
\end{tabular}

Ciência Rural, v.49, n.3, 2019. 
not care about milk fraud scandals (BREITENBACH et al., 2018), and that e results of this research are related to the origin of the product, which is related to product suitability.

Another correlation related to age showed that consumers over 45 years of age are the ones that value "price" the most at the time of milk purchase. The world population is in the process of aging, and in Brazil this phenomenon is also a reality (LOPES et al., 2013). The fact that older people are the group that, in all social classes, tends to have greater availability for consumption, as well as the self-preserving conceptions of the body give new meanings to the aging experience, transforming the elderly into a new actor who is also present in the definition of new consumer markets and forms of leisure (DEBERT, 1997).

c) Regarding income: Consumers with incomes of up to one minimum wage value "promotional offers" when buying milk more than those on other income brackets. There is rational economic behavior in the purchase of milk when it comes to price, and this is an important attribute for most consumers; although, it is not appropriate for individuals with higher income (SOUZA et al., 2013).

Most brands invest in low prices, being a differential for the consumer's decision at time of purchase (SOUZA et al., 2013). In the study by SOUZA et al. (2013) the relationship between price and consumer surpassed brand loyalty. At the time of purchase, many consumers buy the product of lower price since no other significant differences were reported among them.

\section{CONCLUSION}

Considering the economic, contingent and cultural factors that interfere milk demand, "brand" and "price" are the most important factors for Brazilian fluid milk consumers in routine purchase decisions, in that order.

Consumer profile interferes in decisionmaking criteria when purchasing fluid milk. There is a possible market niche to exploit with the elderly, who do not prioritize price when buying milk and are more likely to value more subjective or quality-related aspects. Lower income strata wait for "promotional offers" to buy milk. Although, this seems obvious, it is important for companies to pursue their quest to reach them.

The correlation of the female audience with all consumption conditions is empirically highlighted, while there was a lack of correlations with all variables considering male population. These results should encourage companies to take action in order to cater to the needs of the female market.

The research hypothesis proposed emphasized that attitude and confidence in the product and brand recognition are pre-existing in relation to the purchase decision, due to prior experience derived from previous milk purchases. The hypothesis assumes that the information obtained about the product is unlikely to influence brand recognition, attitude, and trust.

Results corroborated the hypothesis defended by model. In other words, in the milk production chain, the consumption link values prior information, especially the brand, as a priority in the decision to buy fluid milk (especially for women). This is because, along with the product brand, there is correlated information that comes from past purchase experiences, the suitability of the brand (for example, in case of fraud), and the brand's own product attributes that are already known to milk consumers. Thus, Brazilian fluid milk consumers have their purchasing decisions affected by aspects other than the brand. They can opt for cheaper brands, those on sale, or with ready availability.

\section{DECLARATION OF CONFLICTING INTERESTS}

The authors declare no conflict of interest. The founding sponsors had no role in the design of the study; in the collection, analyses, or interpretation of data; in the writing of the manuscript, and in the decision to publish the results.

\section{ACKNOWLEDGEMENTS}

The authors gratefully the Instituto Federal de Educação, Ciência e Tecnologia do Rio Grande do Sul (IFRS) and Universidade Federal de Santa Maria, Santa Maria (UFSM) for their support in conducting the research and the consumers who participated in the research and answered the questionnaire.

\section{AUTHORS' CONTRIBUTIONS}

All authors contributed equally for the conception and writing of the manuscript. All authors critically revised the manuscript and approved of the final version.

\section{REFERENCES}

ASSIS, J. et al. Productive chain of milk in Brazil in the context of international trade. Revista de Ciências Empresariais da UNIPAR, 17(1). 2017. Available from: <http://www.revistas. unipar.br/index.php/empresarial/article/view/5199>. Accessed: Jun. 12, 2018. doi: https://doi.org/10.25110/receu.v17i1.5199. 
BOTELHO, A. R. et al. Design and communication: analysis of the packaging of skim milk. Cadernos UniFOA Especial Design, Volta Redonda, n. 2, p. 103-120, jan. 2015. Available from: $<$ http:// revistas.unifoa.edu.br/index.php/cadernos/article/view/248>. Accessed: Feb. 17, 2018.

BRANDÃO, J. B. etal.Clandestine milk: demand-driven informality-A diagnosis of production and commercialization in Itaqui / Rio Grande do Sul. Extensão Rural, 22(2), 113-131. 2015. Available from: $<$ http://oaji.net/articles/2015/1572-1446324199.pdf $>$. Accessed: Jun. 14, 2018. doi: http://dx.doi.org/10.5902/2318179616027.

BREITENBACH, R. et al. Whose fault is it? Fraud scandal in the milk industry and its impact on product image and consumptionThe case of Brazil. Food Research International, v. 108, p. 475 481. 2018. Available from: < https://www.sciencedirect.com/ science/article/pii/S0963996918302552>. Accessed: Mar. 30, 2018. doi: https://doi.org/10.1016/j.foodres.2018.03.065.

BRENNAN, B. Why She Buys: The new strategy for reaching the world's most powerful consumers, Crowne, New York, NY. 2011.

CHAVES, B. V. et al. Milk market in a small city: consumption behavior and sensory evaluation. Enciclopédia Biosfera, Centro Científico Conhecer - Goiânia, v.13 n.23; p. 2016. 2014, 2016. Available from: <http://www.conhecer.org.br/enciclop/2016a/ agrarias/mercado\%20de\%20leite.pdf $>$. Accessed: Jun. 14, 2018. doi: 10.18677/Enciclopedia_Biosfera_2016_067.

CHURCHILL, G. A. Jr.; PETER, P. J. Marketing: Creating value for customers. 2 ed. São Paulo: Saraiva. 2003.

DEBERT, G. G. The invention of the third age and the rearticulation of forms of consumption and political demands. Revista Brasileira de Ciências Sociais, 12(34), 39-56. 1997. Available from: <http:// www.anpocs.com/images/stories/RBCS/34/rbcs34_03.pdf $>$. Accessed: Jun. 17, 2018.

DÖRR, A. C.; NASCIMENTO, A. R. Economic analysis of the profile of milk consumers in Santa Maria / RS. Anais do 48. Congresso Brasileiro de Economia e Sociologia Rural, Campo Grande, MS. Available from: http://www.sober.org.br/ palestra/15/54.pdf. Accessed: Jun. 17, 2018.

HAIR, J. et al. Fundamentals of research methods in administration. Bookman Companhia. Ed, Sao Paulo, pp 472. ISBN 8536304499. 2005.

HOWARD, J. Consumer Behavior in Marketing Strategy Prentice Hall, New Jersey. 1989.

JATO, R.; LICHT, R. H. G. Automobile-related choices for men and women: Confluence or divergence? Revista Brasileira Gestão e Negócios. São Paulo, Vol.11, n. 30, p.5364. Jan/março. 2009. Available from: <http://www.redalyc.org/ html/947/94711209004/>. Accessed: Mar. 14, 2018.

JOHNSON, L.; LEARNED, A. Why do women buy? Marketing strategies to reach the female audience. Translated from Dont think pink: what really makes women buy - and how to increase your share of this crucial Market. $2^{\mathrm{a}}$ ed. São Paulo, Ed. Saraiva. 2012.
LEITE, R. C. et al. Attributes of credibility and trust valued by the consumers of functional dairy products of the State of Rio Grande do Sul. Revista do Instituto de Laticínios Cândido Tostes, Juiz de Fora, v. 68, n. 392, p. 12-17, mai./jun. 2013. Available from: $<$ https://www.revistadoilct.com.br/rilct/article/view/24/28>. Accessed 14 march 2018. doi: https://doi.org/10.5935//22386416.20130023.

LOPES, E. L.; SILVA, D. Integrative models of consumer behavior: a theoretical review. REMark, v.10, n.3, 3ed. 2011. Available from: <https://search.proquest.com/openview/99e a 82214e967494a8a9741 fc5c41747/1 ? pqorigsite $=$ gscholar\&c bl=496312 $>$. Accessed 14 march 2018. doi: 10.5585/remark. v10i3.2273.

LOPES, E. et al. The new elderly consumer: identification of the relevant retail attributes. RAE - Revista de Administração de Empresas, 53(6), pp.551-564.2013. Available from: <http://www. redalyc.org/articulo.oa?id=155128990004>. Accessed 14 march 2018. doi: http://dx.doi.org/10.1590/S0034-75902013005000002.

MAHAJAN, V. et al. Using innovation diffusion models to develop adopter categories. Journal of Marketing Research, 27, 37-50. 1990.

MALHOTRA, N. K. Marketing research: an applied guideline. 3. ed. Porto Alegre: Bookman, 311p. 2001. Available from: $<$ https://edisciplinas.usp.br/pluginfile.php/4069118/mod resource/content/1/Malhotra_20_AnaliseDeAgrupamentos.pdf $>$. Accessed: Mar. 14, 2018.

MAPA. Ministry of Agriculture, Livestock and Supply (2011). Strategic Agenda. Milk and dairy products 2010-2015. Available from: <http://www.agricultura.gov.br/assuntos/camaras-setoriaistematicas/agendas/arquivos/leite.pdf $>$. Accessed: Mar. 14, 2018.

MARANDOLA, M. E.; LEMANSKI, S. R. Study of the consumer profile of Londrina city supermarkets. Revista Terra e Cultura, $\mathrm{n}^{\circ} 43$, ano 22. Londrina: 41p. 2006. Available from: $<\mathrm{http}: / / \mathrm{web}$. unifil.br/docs/revista_eletronica/terra_cultura/n43/terra_03.pdf $>$. Accessed: Jun. 14, 2018.

MARCONI, M. A.; LAKATOS, E. M. Fundamentals of scientific methodology. 7. ed. São Paulo: Atlas. 2010.

MATTAR, FN. Marketing Research. Compact Edition. 4. ed. São Paulo: Atlas. 314p. 2007.

SANDHUSEN, RL. Basic Marketing. 3. ed. São Paulo: Saraiva. 2010.

SOUZA, A. P. B. et al. Influencing the buying and knowledge about the functional properties of dairy products. Disciplinarum Scientia. Série: Ciências da Saúde, Santa Maria, v. 14, n. 2, p. 273284. 2013. Available from: <https://www.periodicos.unifra.br/ index.php/disciplinarumS/article/viewFile/1055/999>. Accessed: Apr. 2, 2018.

VINUTO, J. Snowball sampling in qualitative research: an open debate. Temáticas, Campinas, 22, (44): 203-220,ago/dez. 2014. Available from: $<$ https://www.ifch.unicamp.br/ojs/index.php/tematicas/article/ view/2144>. Accessed: Jun. 18, 2018. 